RESEARCH NOTE

J. Food Sci. Technol. Nepal, Vol. 8 (78 -80 ) 2013

ISSN: 1816-0727

\title{
Effects of Mild Ingestion of Used Fried Rapeseed Oil (Mustard Oil) on Hepatic Tissues in Long-Evans Rats
}

\author{
M. H. RAHMAN ${ }^{1}$, S. AKTER ${ }^{2}$, T. BEGUM ${ }^{3}$, M. S. I. KHAN ${ }^{4 *}$, M. S. ISLAM ${ }^{5}$ and M. R. BEGUM ${ }^{6}$ \\ ${ }^{1}$ Department of Applied Nutrition and Dietetics, Islamic University, Bangladesh \\ ${ }^{2}$ Department of Human Nutrition and Dietetics, Patuakhali Science \& Technology University, Bangladesh \\ ${ }^{3} \mathrm{ACF}$ international Network, Bangladesh \\ ${ }^{4}$ Department of Food Microbiology, Patuakhali Science \& Technology University, Bangladesh \\ ${ }^{5}$ Department of Post -harvest Technology and Marketing, Patuakhali Science \& Technology University, Bangladesh \\ ${ }^{6}$ Department of Agricultural Economics and Social Science, Chittagong Veterinary \& Animal Sciences University, Bangladesh \\ * Corresponding author: msikhan312@yahoo.com
}

Rapeseed oil (mustard oil), the commonly used cooking oil in rural areas of Bangladesh,containserucic acid (22:1 n-9) that causes harmful effets to human health. The study was conducted on Long-Evans rats to observe the hepatic effect mustard oil. The first group rat used as control fed with flour, while experimental groups 1 and 2 were treated with fried mustard oil ( $2 \mathrm{~g}$ flour $+9 \mathrm{~g}$ oil daily) and erucic acid free mustard oil ( $2 \mathrm{~g}$ flour $+9 \mathrm{~g}$ oil daily) respectively for 5 weeks. Serum indices for three hepatic enzymes Aspartate Transaminase (AST), Alanine Aminotransferase (ALT) and Alanine Phosphatase (ALP), used as the indicator of hepatic activity were analyzed by Dade-Behring auto analyzer. Significant difference of AST, ALT and ALP activity was observed in control and group 2 with group1. Therefore erucic acid of mustard oil has a toxic effect on the hepatic tissue.

Keywords: Mild ingestion, rapeseed oil, hepatic effect, serum indices, long-evans rats

\section{Introduction}

The traditional type is high erucic acid rapeseed (HEAR), generally used for cooking in countries like India and Bangladesh, typically contains between $40 \%$ and $50 \%$ erucic acid, a monounsaturated omega-9fatty acid, denoted 22:1 $\omega-9$ has undesirable effects on healthspecially on cardiac tissue (Kramer et al., 1982). The normal level of AST, ALT and ALP in rat blood is $45.7-80.8 \mathrm{U} / \mathrm{L}, 17.5-30.2 \mathrm{U} / \mathrm{L}$, and $56.8-128 \mathrm{U} / \mathrm{L}$ respectively(Johnson-Delaney C, 1996).AST and ALT are generally considered a measure of hepatocellular function. ALP levels are increased during obstruction of the biliary duct system (Ahmad NZ, 2011). Hepatocellular injury, in which the primary injury occurs to the hepatocytes, Cholestatic injury where the primary injury is to the bile ducts (Esfehet al., 2011). Liver damage, as reflected by the serum concentrations of the enzymes alanine aminotransferase (ALT), aspartate amino -transferase (AST), alkaline phosphatase (ALP), and gamma-glutamyltransferase (GGT) (Folwaczny, 2007; Moussavianet al., 1985). ALT and AST are normally concentrated in the hepatocytes and thus, when present in the serum in elevated concentrations, are markers of liver cell injury. The serum levels of these enzymes start to increase within a few hours of liver cell injury as they leak out of the cells via the damaged cell membrane. AST is less liver-specific than ALT, since AST levels can be elevated not only in liver injury but also in muscle, cardiac, and red blood cell injury (Lepper and Dufour, 2009).Alkaline phosphatase is actually a heterogeneous group of enzymes found mainly in liver and bone cells. Hepatic alkaline phosphatase is concentrated near the biliary canalicular membrane of the hepatocyte. Accordingly, increased levels of hepatic alkaline phosphatase are mainly seen in liver diseases that predominantly affect the biliary system (Aragon and Younossi, 2010). Some European countries have already banned the consumption of mustard oil regarding high erucic acid contents of mustard oil. This is a matter of great concern. The poor illiterate villagers even many literate people of urban area of Bangladesh know little about this oil. That's why they used to consume mustard oil without any hesitation. Few researchers worked on fatty acid composition of mustard and its effect on cardiac tissue but rare initiative has been taken about its toxicity on hepatic tissue. Considering the facts, the authors' plans to investigate the effect of consumption of rapeseed oil (mustard oil) on hepatic tissues in LongEvans rats. 
Materials and Methods

\section{Collection of animals and study treatment}

Six weeks old aged male mice,weighing 20-30 grams, were purchased from International Center for Diarrhoeal Disease Research,Bangladesh(ICDDR'B). The first group was used as control fed with flour, while experimental groups 1 and 2 were treated with fried mustard oil $(2 \mathrm{~g}$ flour $+9 \mathrm{~g}$ oil daily) and erucic acid free mustard oil $(2 \mathrm{~g}$ flour $+9 \mathrm{~g}$ oil daily) respectively for 5 weeks.

\section{Collection and storage of studied (materials) mustard oils}

This was collected from the local retail market where great attention was given to notice the originality of the brands and expire dates of the oils and preserved properly.

\section{Biochemical examination}

After completion of experimental period,blood collected from heart, biochemical assay of AST and ALP, ALT were tested by Dade-Behring auto analyzer.Different organs namely heart, liver, kidney, epididymus adipose tissue, and retro epididymal adipose tissue were isolated and preserved in deep freeze for further investigation.

\section{Statistical Analysis}

Data collected from the study were enter into Spread Sheet Programme of Microsoft Excel Programme-2003 and analyzed by SPSS version 16 were level of significance was $5 \%$ to interpret the results of biochemical parameters.

\section{Results and Discussion}

Figure 1a shows the activity of AST in Unit/Liter of control group, experimental group 1 (FMO) and experimental group 2 (EAFMO) which were ranges from $63 \mathrm{U} / \mathrm{L}$ to $76 \mathrm{U} / \mathrm{L}, 97 \mathrm{U} / \mathrm{L}$ to $103 \mathrm{U} / \mathrm{L}$ and $54 \mathrm{U} / \mathrm{L}$ and $49.5 \mathrm{U} / \mathrm{L}$ with mean $\pm \mathrm{SD}$ of $69.5 \pm 9.19,100 \pm 4.24$ and $51.75 \pm 3.18$ respectively whereas Figure $1 \mathrm{~b}$ shows the activity of ALT in Unit/Liter in three groupsranges from $22 \mathrm{U} / \mathrm{L}$ to $26 \mathrm{U} / \mathrm{L}, 43 \mathrm{U} / \mathrm{L}$ to $48 \mathrm{U} / \mathrm{L}$ an $\mathrm{d} 18 \mathrm{U} / \mathrm{L}$ to 20.5 $\mathrm{U} / \mathrm{L}$ with mean $\pm \mathrm{SD}$ of $24 \pm 2.82,45.5 \pm 3.53$ and 19.25 \pm 1.76 respectively and Figure 1c shows the activity of ALP in Unit/Liter indicated from $78 \mathrm{U} / \mathrm{L}$ to $86 \mathrm{U} / \mathrm{L}, 134$ $\mathrm{U} / \mathrm{L}$ to $146 \mathrm{U} / \mathrm{L}$, and $65 \mathrm{U} / \mathrm{L}$ to $76.50 \mathrm{U} /$ Lwith mean $\pm \mathrm{SD}$ of $80.5 \pm 3.53,140 \pm 8.48$ and $70.75 \pm 8.13$ respectively. The activity was plotted against groups and a curve was obtained. For each test of serum,In experimental group 1 comparing with the experimental group 2 the activity were found higher and statistically significant $(p<0.05)$. In group 2 the activity was lower compared to control group which indicated that in erucic acid free diet the activity of AST was lower. There was observed significant difference between control and group $1(\mathrm{p}<0.05)$.

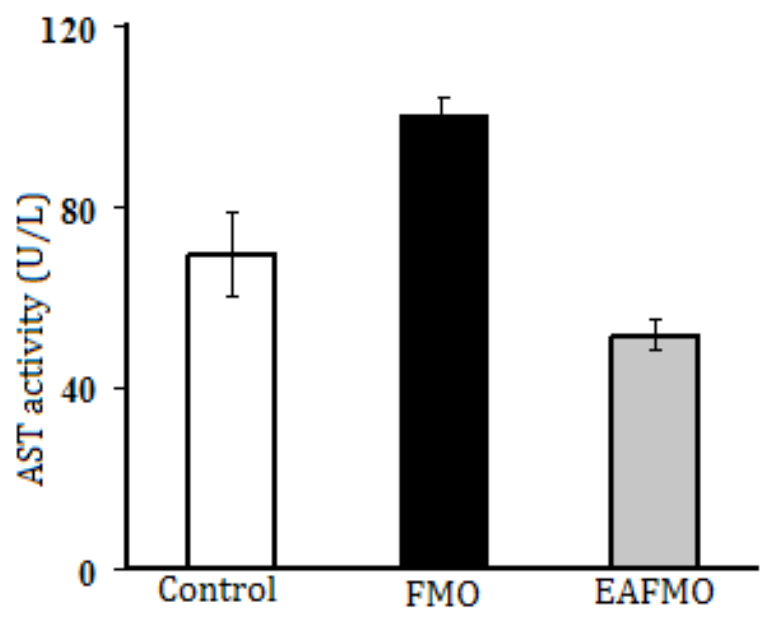

Figure 1a. AST assay from serum

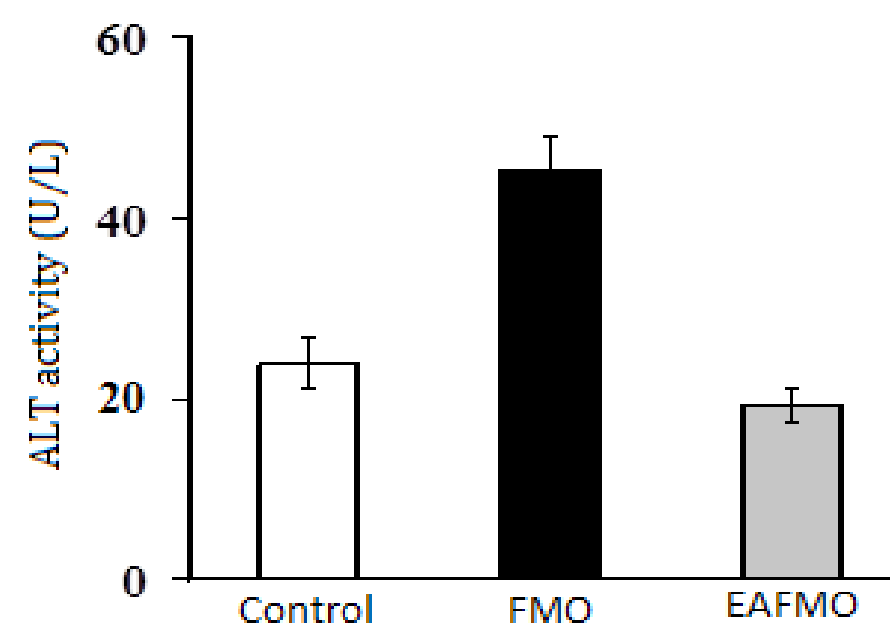

Figure 1b. ALT assay from serum

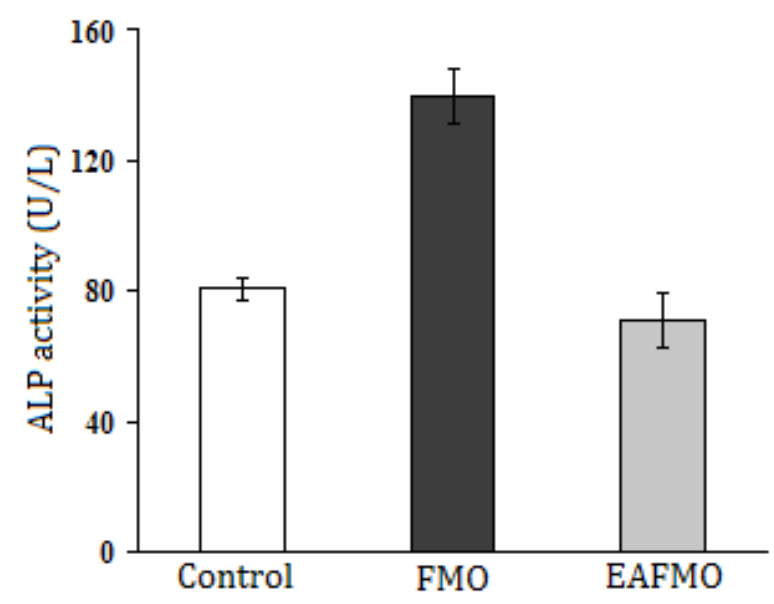

Figure 1c. ALP assay from serum 
Rahman et al.: J. Food Sci. Technol. Nepal, Vol. 8 (78-80 ), 2013

This study was to investigate the effect of fried mustard oil on hepatic tissues in Long-Evans rats. Aspartate Transaminase (AST), Alanine Transaminase (ALT) and Alanine Phosphatase (ALP) activity were observed for the monitoring of hepatic health. In the experimental group1 each enzymes was significantly higher than other two groups indicate the hepatic injury of thr experimental rat.ALT and AST are markers of liver cell injury, normally concentrated in the hepatocytes,start to increase within a few hours through the damaged cell membrane although AST is less liver-specific than ALT (Lepperand Dufour, 2009).

Alkaline phosphatase, found mainly in liver and bone cells, concentrated near the biliary canalicular membrane of the hepatocyte, mainly seen in liver diseases that predominantly affect the biliary system (Aragon andYounossi, 2010).

\section{Conclusions}

In this study, the author also investigated whether erucic acid was harmful for liver or not and it was found harmful. However, the further stage of research might be the investigation of the specific biological effects of erucic acid on liver and how it could be prevented. Beside the above mentioned tests another hepatic markers can be investigated for further confirmation of mustard oil and hepatic effect. However, since erucic acid is harmful to health so the commercial production of erucic acid free varieties and processing of erucic acid free mustard oil should be encouraged in Bangladesh.

\section{References}

Aragon G., Younossi Z.M. (2010). When and how to evaluate mildly elevated liver enzymes in apparently healthy patients. Cleve Clin J Med, 77:195-204.

Esfeh J.M., Hanouneh I. A., Zein and N. N.(2011). A 25-year-old man with very high alkaline phosphatase, Cleve Clin J Med, 78(12):794.

Folwaczny C. (2007). Efficient diagnostics for elevated trans -aminases. [Article in German] MMW Fortschr Med;149:44-48.

Johnson-Delaney C. (1996). Exotic Animal Companion Medicine Handbook for Veterinarians, Zoological Education Network

Kramer J.K., Farnworth E.R., Thompson B.K., Corner A.H. and Trenholm H.L. (1982) "Reduction of myocardial necrosis in male albino rats by manipulation of dietary fatty acid levels". 17 (5): 372-82

Lepper P.M. and Dufour J.F. (2009). Elevated transaminases-what to do if everything was done?Article in German] Praxis (Bern 1994), 98:330-334.

Moussavian S.N., Becker R.C., Piepmeyer J., Mezey E. and Bozian R.C. (1985). Serum gammaglutamyltranspeptidase and chronic alcoholism. Influence of alcohol ingestion and liver disease. Dig Dis Sci, 30:211-214.

Nasir ZaheerAhmad J.S.L.S.( 2011) Jan-Mar, 15(1): 65-69 